
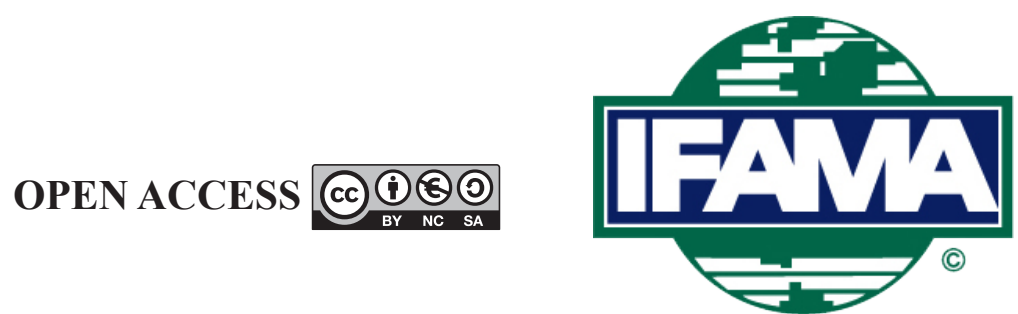

International Food and Agribusiness Management Review

Volume 24, Issue 2, 2021; DOI: 10.22434/IFAMR2020.0035

Received: 5 March 2020 / Accepted: 30 October 2020

\title{
How has the minimum support price policy of India affected cross-commodity price linkages?
}

\section{RESEARCH ARTICLE}

\author{
Luis Emilio Morales ${ }^{\circledR a}$, Jean Baliéb and Emiliano Magrini ${ }^{\mathrm{c}}$ \\ ${ }^{a}$ Senior Lecturer in Agricultural Economics, UNE Business School, \\ University of New England, W40 EBL Building, Armidale, NSW 2351, Australia \\ ${ }^{b}$ Agri-Food Policy Platform Head, Agri-Food Policy Platform, International Rice \\ Research Institute (IRRI), Pili Drive, Los Baños, 4031, Philippines
}

${ }^{c}$ Economist, Agricultural Development Economics Division (ESA), Food and Agriculture Organization of the United Nations (FAO), Viale delle Terme di Caracalla, Rome, 00153, Italy

\begin{abstract}
For several decades, the government of India has implemented a minimum support price (MSP) policy for agricultural commodities to reduce price risk levels for farmers. Concerns have been raised about whether this policy could affect market integration of related agricultural products, modify price incentives, and ultimately alter resource allocation and production between commodities. This study uses a panel vector auto-regression model across six states for the period 2002-2017 to analyse the effects of the MSP on the transmission of price shocks between cereals and oilseeds. The results demonstrate that the MSP partially and completely offsets price linkages between agricultural commodities, potentially introducing distortions in price incentives that affect land allocation and production between commodities. Beyond the effects of the MSP across commodities, Indian authorities can expect that price shocks on maize be transmitted to soybean over the next production period. Finally, this study demonstrates that the use of alternative data frequencies can identify differences in market reactions over time that can be related to production cycles and delays in price transmission.
\end{abstract}

Keywords: commodity prices, minimum support prices, panel vector auto-regression, India JEL code: M21, Q13, Q18

${ }^{\oplus}$ Corresponding author: emilio.morales@une.edu.au 


\section{Introduction}

Price fluctuations in agricultural commodity markets are a key policy issue for governments and international organizations. The large and unpredictable price variations of agro-food products observed during the last major food price crises of 2007-08 and 2011-12 have not only increased the price risk for farmers, traders and retailers, but have also affected the net incomes of farmers and their capacity to invest in their business. Price variability has also dramatically influenced the level of consumption of food items across countries (Dawe et al., 2015; Minot, 2014). The Food and Agriculture Organization of the United Nations (FAO) states that the level of price fluctuations exhibited during and after the food price crises is likely to continue in the medium term, negatively affecting producers, processors and consumers (FAO, 2011).

Dawe and Timmer (2012) and Jayne et al. (2008) state that numerous countries have introduced policies to stabilize prices and mitigate the negative effects of large price fluctuations. These government interventions seek to reduce the risk associated with excessive price variability. Such policy instruments set prices at levels that incentivize farmers to produce, but at the same time keep prices at affordable levels for consumers in order to guarantee food security among the population (FAO, 2011; Jayne et al., 2008; Minot, 2014; Sekhar, 2012). Governments have faced several challenges when setting these price levels. The price support policies of governments have primarily favoured the supply side, as they have attempted to achieve their policy objectives of food security or farmers' income by incentivizing the production of specific commodities they consider strategic priorities. In other words, interventions on farm output prices have aimed to: (1) influence the allocation of farm resources and production; (2) alter and stabilize income distribution; and (3) either incentivize or discourage investment and capital formation in different agro-food industries by reducing the price risk (Ellis, 1992). However, price interventions have important side effects, one of which is the allocation of land and other resources to the production of different commodities (Deaton, 1999; Dethier and Effenberger, 2012). This impact on allocation can alter the competitiveness of specific agro-food industries or even the complete agricultural sector relative to other economic sectors.

Knowledge about the effects of price interventions on price fluctuations across agro-food commodities is key when implementing these policies; however, beyond the information on the direct intervention in each product, there is currently a lack of evidence about these effects. Depending on the degree of substitution between agro-food products on production and consumption, when prices vary, producers adjust the quantities they supply to maximize profits while consumers adjust their demand to minimize expenditure (Saadi, 2011). Under competitive conditions, these variations in the quantities traded of different products are expected to affect their relative prices and to result in a market integration of related commodities (Esposti and Listorti, 2013; Tomek and Kaiser, 2014). Previous research has reported relationships between commodity prices based on their co-movements (Ai et al., 2006; Pindyck and Rotemberg, 1990; Saadi, 2011), and Esposti and Listorti (2013) reported cross-commodity price linkages between durum wheat and corn prices in Bologna, Rome and Rotterdam markets. Additionally, macroeconomic factors such as economic growth, inflation, exchange rates and interest rates can simultaneously influence the dynamics of agricultural commodity markets (Byrne et al., 2013; Palaskas and Varangis, 1991; Saadi, 2011).

Considering the substantial price interventions in agro-food products implemented in several countries (OECD, 2018a) and the potential spill-over effects between related products, there is a need to learn more about these interactions. Policy makers are also interested in how price support policies can influence production incentives across commodities, and how these incentives affect the pass-through of price signals across commodity markets, the resource reallocation of land, and, ultimately, the extent to which those policies can potentially undermine the overall performance of the agricultural sector.

In India, the Commission for Agricultural Costs and Prices (CACP) annually recommends a minimum support price (MSP) for the following production year. After that, the government sets the MSP based on the recommendations and market conditions (McCorriston and MacLaren, 2016). Through this strategy, the government of India aims to guarantee minimum prices for the most relevant commodities and provides a 
buffer to farmers against sharp price falls while tackling potential market imperfections (Ali et al., 2012). However, Aditya et al. (2017), Chand (2003) and Singh et al. (2002) indicate that because the MSP has favoured food crops more than other crops, they consider that it has caused a large reallocation of land away from oilseeds to paddy and wheat.

This article contributes to the literature by estimating the effects of the MSP policy in India and whether there are remaining cross-commodity price linkages between cereals and oilseeds, once the effects of the MSP are taken into account. Kumar (2006) analysed price linkages within cereals, pulses, oilseeds and edible oils complexes in India with a focus on consumer product substitution, but there has been no investigation of the potential price linkages between commodities of different complexes that result from production substitution followed by farmers and the effects of the MSP. As far as the authors know, this is the first study that investigates the dynamics of price linkages between agricultural commodities in different commodity complexes under market price intervention. This research uses a panel vector auto-regression (PVAR) approach to model data of paddy rice, maize and soybean from six relevant states in India to identify price shock transmissions beyond the effect of the MSP. This study uses data of alternative time frequencies to test differences in the models due to dynamic market reactions related to the characteristics of agricultural commodity markets at farmer-wholesaler level in India. These characteristics are production cycles, previously agreed contracts and lags on price transmission with respect to variations in retail prices (Fackler and Goodwin, 2001; Meyer and Von Cramon-Taubadel, 2004).

The insights of this study are relevant for policy makers because, as expected, it is found that a MSP policy applied to one commodity can have effects on the market prices of other commodities. More importantly, the results show when the effects of the price intervention are removed, only some of the price relationships between cereals and oilseeds remain, which implies the introduction of price distortions by the MSP policy in Indian markets that affect the transmission of price signals that would normally adjust production levels among the three crops.

The remainder of this article is organized as follows. Section 2 discusses the price transmission in Indian agricultural markets and the intervention policies implemented to reduce price risk and support farmers' incomes. Section 3 describes the methodology of analysis used in this research. Section 4 presents the panel data for the six Indian states analysed. Section 5 reports the results of the PVAR modelling. Finally, Section 6 discusses the main conclusions related to policy decisions that can be derived from the results.

\section{Price interventions and transmissions in Indian agricultural markets}

The transmission of shocks from world to domestic prices has been used as a measure of market integration, as under free market conditions, domestic prices are expected to be influenced by price fluctuations in international markets (Morales, 2018; Newton, 2016; Rapsomanikis and Mugera, 2011). According to Fackler and Goodwin (2001) and Meyer and Von Cramon-Taubadel (2004), in agricultural markets, especially those in developing countries, there are asymmetries and lags in price transmission that reduce the level of market integration. Several factors could affect price transmission in agricultural markets, including market power, time lags in supply and demand, contracts, quality risk, technical change, transport and transaction costs, perishability of the product, available infrastructure, temporary sales and public interventions (Baquedano and Liefert, 2014; Conforti, 2004; Fackler and Goodwin, 2001; Meyer and Von Cramon-Taubadel, 2004; Nourou, 2015; Rapsomanikis and Mugera, 2011; Rezitis, 2018).

There are several conditions in India that impact on the effect of price transmission. Conforti (2004) and Acharya et al. (2012) reported that there is a long-run equilibrium in the transmission of price shocks in cereals from the international and wholesale markets to farm-gate; however, these adjustments require more time and there are transmission asymmetries in markets located in the southern region compared to the rest of the country. Moreover, Indian cereal markets that experience movement restrictions between states, such as rice, do not show signs of market integration at the national level (Sekhar, 2012). Another condition 
identified by Kumar (2006) is that there are inter-commodity price linkages of cereals, pulses, oilseeds and edible oils in India, with prices of commodities moving together within each commodity complex. In addition, Mittal et al. (2018) reported that in the presence of substantial market interventions, the volatility of domestic rice and wheat prices in India is mostly due to internal production shocks rather than fluctuations that originate in international markets. Under these conditions, several governments have implemented price policy interventions to protect consumers and farmers and achieve higher levels of food security.

The MSP is a key component of the agricultural price policy of India. In 1965, the government of India established the Agricultural Prices Commission (APC), later renamed the Commission for Agricultural Costs and Prices (CACP), to set the prices for crops (Acharya, 1997). For several decades, the government has implemented MSP for 25 agricultural commodities based on their estimated cost of production. The price interventions in India and other countries have aimed to reduce the risk of rapid or erratic changes in price level, as studied in sub-Saharan Africa by Magrini et al. $(2017 \mathrm{a}, \mathrm{b})$. The government of India intends that application of this policy would ensure that farmers receive prices that allow them to cover the costs of production, achieve some profits (McCorriston and MacLaren, 2016) and increase the production of key commodities to guarantee food security (Saini and Gulati, 2017). Aditya et al. (2017) and Chand (2008) state the MSP policy has been successful in increasing food production in India, since the MSP is perceived by farmers as being a safety net for guaranteeing commodity prices, which is key for their long-term investment decisions. However, concerns have been raised about the effectiveness and effects of the MSP, with procurements made only in a few states and with support that favours food crop specialization to the detriment of other products, including oilseeds (Aditya et al., 2017; Ali et al., 2012; Chand, 2003; Singh et al., 2002).

\section{Theoretical and methodological approach}

Byrne et al. (2013), Palaskas and Varangis (1991) and Saadi (2011) state that under normal market conditions, the price of a specific commodity depends on supply and demand of the product, and are also influenced by prices of other related products, such as inputs or substitutes, as well as macroeconomic variables that affect the overall economy. In addition, the MSP policy can affect price transmission (Conforti, 2004; Fackler and Goodwin, 2001) and it may affect price linkages between agricultural commodities. Consequently, the MSP was included in the empirical model tested in this study to determine its effects on prices of the same product and other related commodities.

The empirical model also includes lags of commodity prices as a way to capture the delayed effects previously mentioned of price adjustments in agro-food markets (Conforti, 2004; Fackler and Goodwin, 2001; Rapsomanikis and Mugera, 2011; Rezitis, 2018), following recursive adjustments over time, where prices paid by wholesalers at time $t$ depend on prices paid in previous periods. In other words, farmers are expected to consider the prices paid in previous seasons in their adaptive expectations of the prices they could receive at the end of the current season (Tomek and Kaiser, 2014).

Finally, constraints on land and resources mean that there are linkages between commodity prices due to substitution in production that could be influenced by changes in the MSP of different commodities. These linkages could offset and, in some cases, even exceed in magnitude the effect on other commodities of a price change in one commodity. The spatial price transmission between states has not been considered in the model given the trade restrictions between states implemented by the government of India.

These relationships are tested in the following dynamic panel model:

$$
P_{i t}=\Gamma_{0}+\sum_{s=1}^{S<T} \Gamma_{S} P_{i t-s}+\beta X_{i t}+\gamma M S P_{i t}+\delta d_{i t}+\mu_{i}+e_{i t}
$$

where $P_{i t}$ is a vector of endogenous commodity prices paid by wholesalers in state $i$ at time $t, X_{i t}$ is a matrix of exogenous macroeconomic variables, $M S P_{i t}$ is a vector of minimum support prices in state $i$ at time $t, d_{i t}$ 
is a matrix of exogenous quarter or seasonal dummy variables, $\Gamma_{0}$ is a vector of intercepts, $u_{i}$ is a vector of state-level fixed effects and $e_{i t}$ is a vector of stochastic errors.

It is plausible that in the context of price interventions, as discussed above, the price variation in one commodity that is influenced by price changes in other products could be partially or completely offset or even exceeded by variations in the MSP. In such a case, no remaining cross-commodity price linkages would be observed after removing the effect of the price intervention on each commodity; otherwise, the commodity price would further adjust. The concept of 'deviation payments' is used to study the price relationships between agrofood products that are only due to market adjustments and exclude the effects of government intervention through MSP, in the same way as used by Ali et al. (2012). These deviations represent the price difference between the prices paid by wholesalers and the MSP set by the government of India for each product during one year (MSP period). Therefore, based on Equation 1, the empirical model for price deviations between commodity prices paid by wholesalers and the MSP used in this study is:

$$
P D E V_{i t}=\Gamma_{0}+\sum_{s=1}^{S<T} \Gamma_{s} P D E V_{i t-s}+\beta X_{i t}+\gamma M S P_{i t}+\delta d_{i t}+\mu_{i}+e_{i t}
$$

where $P D E V_{i t}$ is a vector of endogenous price deviations between commodity prices paid by wholesalers and the MSP in state $i$ at time $t$, and the rest of the equation remains unchanged.

A stationary time-series process has a constant mean, variance and autocorrelations for each period (Enders, 2014). When non-stationary panel data are regressed, they may incorrectly appear to be related with trending over time. This is known as 'spurious panel regression' (Kao, 1999). In addition, when a linear combination of non-stationary variables is stationary, the variables can be categorized as being co-integrated (Enders, 2014; Greene, 2018; Kao, 1999). In the event the variables are non-stationary integrated of order 1, there will be no co-integration; however, relationships between the variables included in the model presented in Equation 2 could remain (Ahn and Lee, 2015). Therefore, they can be adjusted by using first differences to avoid the potential bias of 'spurious regression':

$$
\Delta P D E V_{i t}=\Gamma_{0}+\sum_{s=1}^{S<T} \Gamma_{s} \Delta P D E V_{i t-s}+\beta \Delta X_{i t}+\gamma \Delta M S P_{i t}+\delta d_{i t}+\mu_{i}+e_{i t}
$$

where $\triangle P D E V_{i t}$ is a vector of endogenous first differences of price deviations between commodity prices paid by wholesalers and the MSP in state $i$ at time $t, \Delta X_{i t}$ is a matrix of exogenous first differences of macroeconomic variables, $\triangle M S P_{i t}$ is a vector of exogenous first differences of minimum support prices in state $i$ at time $t, d_{i t}$ is a matrix of exogenous quarter or seasonal dummy variables, $\Gamma_{0}$ is a vector of intercepts, $u_{i}$ is a vector of state-level fixed effects and $e_{i t}$ is a vector of stochastic errors.

Dynamic regression models that have vector auto-regression (VAR) have been used in several studies to test the impact of price shocks over time, given the nature of price adjustments, including Morales et al. (2017), Myers et al. (1990) and Sims (1980). Moreover, the VAR model represents a useful alternative approach under limited data conditions when it is not possible to implement a traditional structural econometric approach (Jayne et al., 2008). Then, the vector moving average (VMA) representation of the VAR can be used to trace out the responses to shocks to each variable, using impulse response functions (IRF) to describe the reaction of one variable to a shock in another variable in the system, keeping all other variations equal to zero (Love and Zicchino, 2006; Sims, 1980). A one-unit shock is applied through the IRF to the error of each equation to obtain the effects over time. The one-unit shock in the error of a specific variable at time $t$ will cause the value of that variable to increase by one unit at time $t$, resulting in variations in that variable and others in subsequent periods when there are no contemporaneous effects (Enders, 2014).

The use of panel data for empirical studies has become increasingly popular, given that panels control for individual heterogeneity and provide more data, more degrees of freedom, more variability, less collinearity between variables and greater efficiency. However, the units are likely to exhibit cross-sectional dependence 
or correlation among those groups included in the panel when analysing cross-sections of states, which might affect the validity of test results (Baltagi, 2013; Greene, 2018).

Love and Zicchino (2006) were among the first scholars to implement a VAR model using panel data to investigate dynamic investing behaviour among firms in different countries. The panel VAR (PVAR) combines the traditional VAR of endogenous variables with the panel-data approach, which allows for unobserved individual heterogeneity (Abrigo and Love, 2016; Love and Zicchino, 2006). Moreover, the PVAR allows assessing the interaction between the prices of two products without introducing assumptions about their causation and the time length over which the variables affect each other (Klein, 2009). The lags in the dependent variable result in the fixed effects variables being correlated with the dependent variables; therefore, the PVAR estimation uses a 'Helmert's procedure' to remove the mean of all forward observations available for each state-year (Arellano and Bover, 1995). This procedure is used to preserve the orthogonality between transformed variables and lagged endogenous variables, which can then be used as instruments to estimate the coefficients that rely on a system Generalized Method of Moments (GMM), following the PVAR estimation routine developed by Love and Zicchino (2006).

\section{Data}

Modal prices paid by wholesalers for a quintal of paddy rice, maize and soybean in daily transaction records in the Indian states of Chhattisgarh, Gujarat, Karnataka, Madhya Pradesh, Maharashtra and Rajasthan between quarter 4, 2001 and quarter 3, 2017 were obtained from the Open Government Data Platform India $^{1}$ (Government of India, OGDP, 2018). These three agricultural commodities were used for this study given their relevance for both production and consumption in the Indian agricultural sector, and taking into consideration data availability. Rice is the most important food crop in India when considering its area, production, consumption and value of exports. Maize is an emerging crop that grows under varied agro-climatic conditions and currently is the third most important cereal crop, with an increasingly relevant export value. India is one of the major exporters of soybean meal, which is used as animal feed and fertilizer. Soybean represents an important export value for the economy (Saini and Gulati, 2017). According to the government of India, Ministry of Statistics and Programme Implementation (2018), during the production year $2015 / 16$, the states selected in this study represented $16.3 \%$ of total paddy rice production, $42.8 \%$ of total maize production and $96.2 \%$ of total soybean production, covering the most relevant area that produces soybean in India (Table 1).

Table 1. Total production and percentages of selected states in India for the period 2015/16. ${ }^{1}$

\begin{tabular}{|c|c|c|c|c|c|c|}
\hline \multirow[b]{2}{*}{ States } & \multicolumn{3}{|c|}{ Total production $(\times 1000$ tones $)$} & \multicolumn{3}{|c|}{ Percentage production } \\
\hline & Paddy rice & Maize & Soybean & Paddy rice & Maize & Soybean \\
\hline Chhattisgarh & $6,094.2$ & 193.8 & 69.0 & 5.8 & 0.9 & 0.8 \\
\hline Gujarat & $1,670.0$ & 572.0 & 54.0 & 1.6 & 2.6 & 0.6 \\
\hline Karnataka & $2,702.0$ & $3,269.0$ & 135.0 & 2.6 & 15.0 & 1.6 \\
\hline Madhya Pradesh & $3,578.8$ & $2,580.3$ & $4,907.9$ & 3.4 & 11.8 & 57.1 \\
\hline Maharashtra & $2,627.0$ & $1,511.0$ & $2,101.2$ & 2.5 & 6.9 & 24.5 \\
\hline Rajasthan & 369.8 & $1,210.4$ & 998.8 & 0.4 & 5.6 & 11.6 \\
\hline Total selected states & $17,041.8$ & $9,336.5$ & $8,265.8$ & 16.3 & 42.8 & 96.2 \\
\hline Total India & $104,316.8$ & $21,806.5$ & $8,591.8$ & 100.0 & 100.0 & 100.0 \\
\hline
\end{tabular}

${ }^{1}$ Data collected from the Statistical Year Book India (Government of India MSPI, 2018).

\footnotetext{
$13 \%$ of the data were imputed using a linear regression method, as the transaction record system was not completely implemented in all states at the beginning of the period under analysis.
} 
The MSP, including any additional bonus when given, was removed from each transaction record to estimate the daily price deviations. The MSP was used for the year span implemented by the government of India, comprising the period between the fourth quarter of a specific year and the following year's third quarter (Government of India, MACP, 2018). The averages of modal prices and price deviations were estimated per quarter, season (semi-annual) and annum, according to the MSP year. These values were deflated to the Indian rupee (INR) ${ }^{2}$ of quarter 1, 2010, using the Consumer Price Index (CPI) reported by the International Monetary Fund (IMF) (2018). The average real modal prices for the six selected states and the MSP (base quarter 1, 2010) for the three commodities are plotted (Figure 1).

Prices paid by wholesalers for the three commodities have fluctuated mostly above the MSP during the period under analysis, which supports the claim by the Indian authorities that the MSP plays out as a reference, with market price varying above the MSP. As reported by Aditya et al. (2017), Chand (2003) and Singh et al. (2002), the level of support guaranteed by the MSP is lower in soybean with respect to the average prices paid by wholesalers, allowing for bigger spreads and fluctuations. In contrast, the average level of support observed for paddy rice and maize is higher, with their MSP closer to the average prices paid by wholesalers. In addition, the commodity prices appear to move together, which is in line with the outcomes reported by Ai et al. (2006), Esposti and Listorti (2013), Pindyck and Rotemberg (1990) and Saadi (2011). The potential relationships between commodities will be further investigated to determine the proportion of variation that is purely due to market linkages.

Previous studies, including Byrne et al. (2013) and Saadi (2011), included oil prices and economic growth in the estimations as macroeconomic exogenous variables; therefore, these were included in the estimations in this study. Oil basket prices per barrel for the same period from the Organization of the Petroleum Exporting Countries (OPEC) were used (OPEC, 2018). These prices were converted to Indian rupees and deflated using the exchange rates and CPI provided by the IMF (2018). Finally, the real economic growth rates were calculated using the real GDP 2010 reported by the OECD (2018b).

\section{Empirical results}

The first test performed was the Pesaran (2004) error cross-sectional dependence CD-test for commodity prices and price deviations for the quarterly, semi-annual and annual series. In all cases, the test confirmed the presence of cross-sectional dependence in price and price deviation series (Table 2), with all tests rejecting the null hypothesis of cross-section independence, which could be influenced by the MSP set by the government during the period under analysis.

The second set of tests performed were the Levin et al. (2002) demeaned panel unit-root test and the Breitung and Das (2005) robust panel unit-root test in all panel series, which would avoid the potential bias effects of cross-sectional dependence. The results of the panel unit-root tests (Table 3) demonstrate that most of the prices and price deviations are stationary or integrated of order $0(I(0))$, while some cases are non-stationary in level but stationary in first differences or integrated of order $1(I(1))$.

This study uses series in first differences, given the results of the panel unit-root tests. The variables do not meet the co-integration requirement due to the different orders of integration (Baltagi, 2013); hence, this research uses a PVAR model.

\footnotetext{
${ }^{2}$ According to IMF (2018), during quarter 3 2017, 64.28 Indian rupees (INR) were equivalent to 1 US dollar (USD).
} 
A

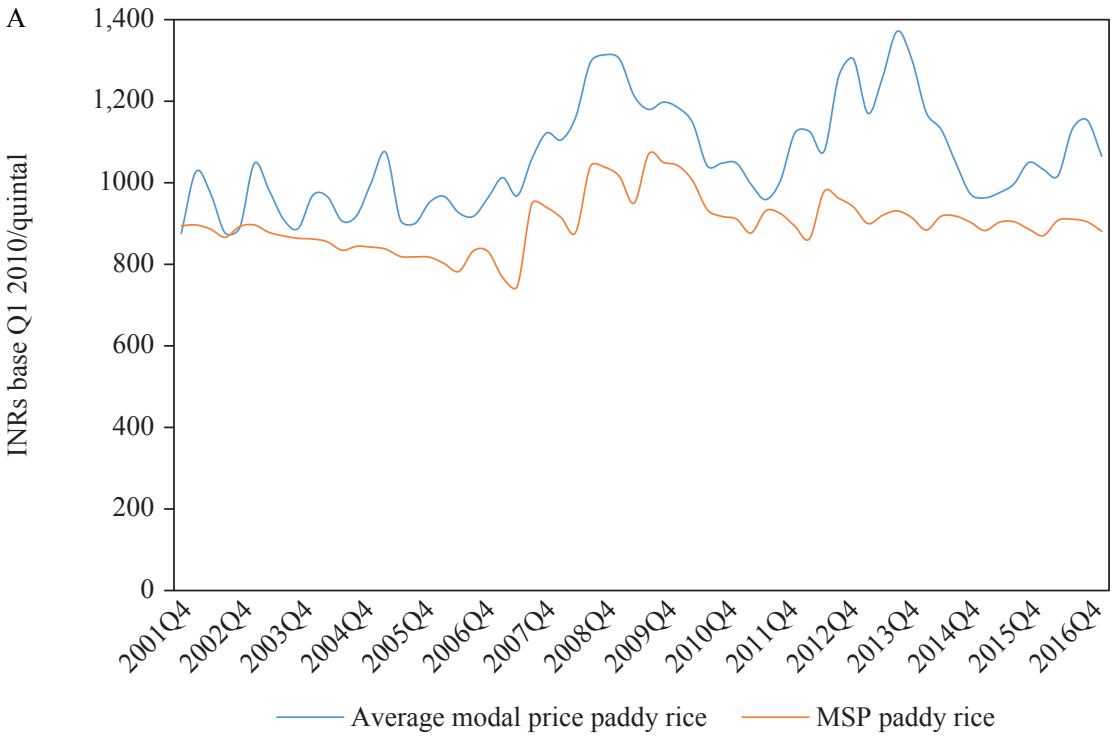

B

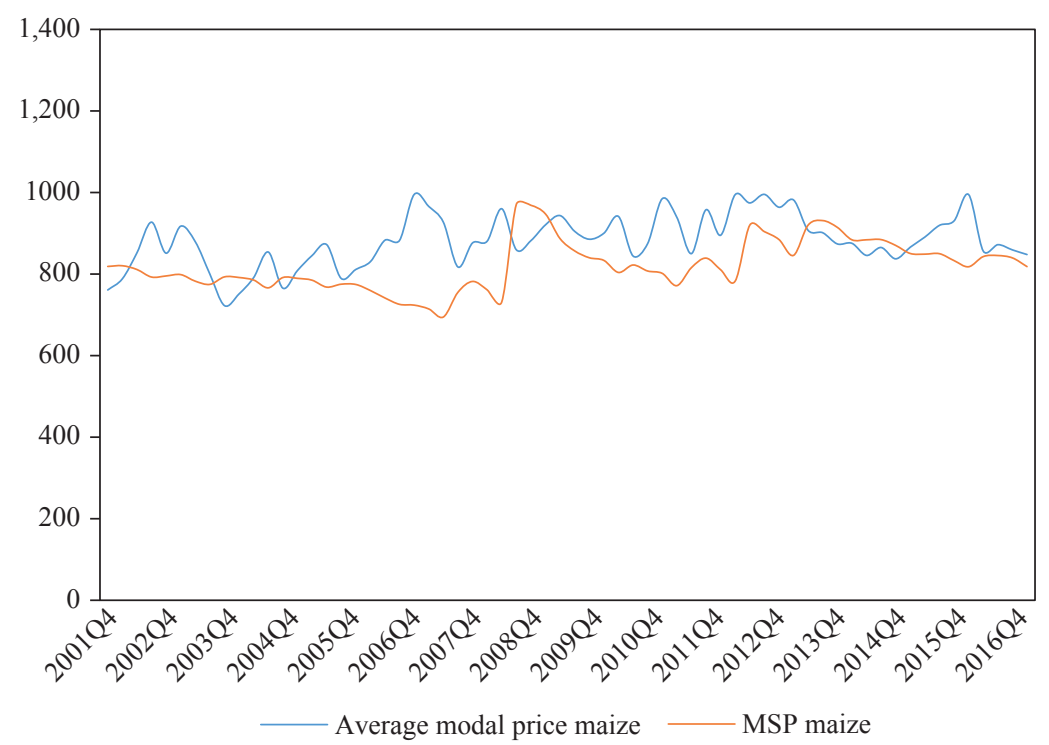

$\mathrm{C}$

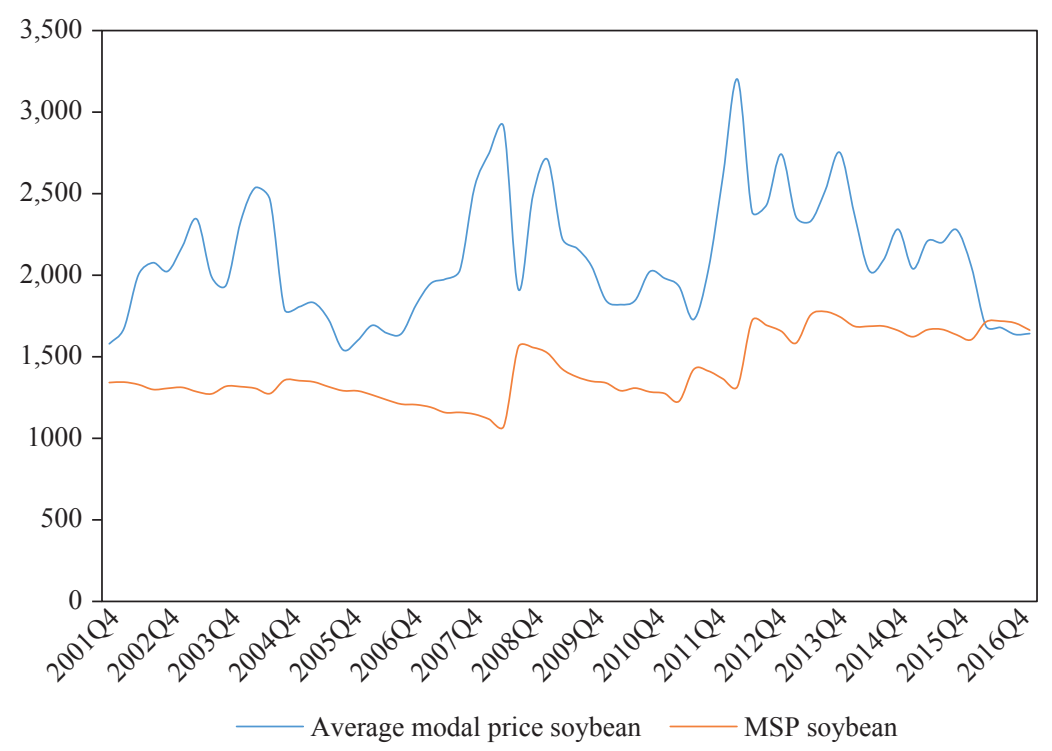

Figure 1. Average modal prices paid by wholesalers and minimum support price for paddy rice (A), maize (B) and soybean (C) between 2001Q4 and 2017Q3 (in INRs base quarter 1, 2010). 
Table 2. Pesaran (2004) error cross-section dependence CD-test results of price and price deviation series. ${ }^{1}$

\begin{tabular}{|c|c|c|c|}
\hline Series & $\begin{array}{l}\text { Pesaran (2004) } \\
\text { CD-test quarterly }\end{array}$ & $\begin{array}{l}\text { Pesaran (2004) } \\
\text { CD-test semi-annual }\end{array}$ & $\begin{array}{l}\text { Pesaran (2004) } \\
\text { CD-test annual }\end{array}$ \\
\hline Price of paddy rice (INR base 2010Q1/quintal) & $15.62 * * *$ & $12.15 * * *$ & $9.70 * * *$ \\
\hline Price of maize (INR base 2010Q1/quintal) & $18.07 * * *$ & $12.76^{* * *}$ & $8.98 * * *$ \\
\hline Price of soybean (INR base 2010Q1/quintal) & $29.66 * * *$ & $21.20 * * *$ & $15.02 * * *$ \\
\hline $\begin{array}{l}\text { Price deviation of paddy rice (INR base 2010Q1/ } \\
\text { quintal) }\end{array}$ & $8.76^{* * *}$ & $6.53 * * *$ & $4.06 * * *$ \\
\hline Price deviation of maize (INR base 2010Q1/quintal) & $22.09 * * *$ & $15.78 * * *$ & $11.16^{* * *}$ \\
\hline $\begin{array}{l}\text { Price deviation of soybean (INR base 2010Q1/ } \\
\text { quintal) }\end{array}$ & $29.66 * * *$ & $21.23 * * *$ & $15.06 * * *$ \\
\hline
\end{tabular}

${ }^{1}$ Under the null hypothesis of cross-section independence, $\mathrm{CD} \sim \mathrm{N}(0,1)$.

Table 3. Panel unit root test results of series. ${ }^{1}$

\begin{tabular}{|c|c|c|c|c|c|c|c|c|c|c|c|c|}
\hline & \multicolumn{4}{|l|}{ Quarterly } & \multicolumn{4}{|c|}{ Semi-annual } & \multicolumn{4}{|l|}{ Annual } \\
\hline & \multicolumn{2}{|c|}{$\begin{array}{l}\text { Levin } \text { et al. (2002) } \\
\text { adjusted } t^{*} \text {-test } \\
\text { statistic }\end{array}$} & \multicolumn{2}{|c|}{$\begin{array}{l}\text { Breitung and Das } \\
\text { (2005) lambda-test } \\
\text { statistic }\end{array}$} & \multicolumn{2}{|c|}{$\begin{array}{l}\text { Levin et al. (2002) } \\
\text { adjusted } t^{*} \text {-test } \\
\text { statistic }\end{array}$} & \multicolumn{2}{|c|}{$\begin{array}{l}\text { Breitung and Das } \\
\text { (2005) lambda-test } \\
\text { statistic }\end{array}$} & \multicolumn{2}{|c|}{$\begin{array}{l}\text { Levin } \text { et al. (2002) } \\
\text { adjusted } t^{*} \text {-test } \\
\text { statistic }\end{array}$} & \multicolumn{2}{|c|}{$\begin{array}{l}\text { Breitung and Das } \\
\text { (2005) lambda-test } \\
\text { statistic }\end{array}$} \\
\hline & Level & First diff. & Level & $\begin{array}{l}\text { First } \\
\text { diff. }\end{array}$ & Level & $\begin{array}{l}\text { First } \\
\text { diff. }\end{array}$ & Level & $\begin{array}{l}\text { First } \\
\text { diff. }\end{array}$ & Level & $\begin{array}{l}\text { First } \\
\text { diff. }\end{array}$ & Level & $\begin{array}{l}\text { First } \\
\text { diff. }\end{array}$ \\
\hline $\begin{array}{l}\text { Price of paddy rice (INR base } \\
\text { 2010Q1/quintal) }\end{array}$ & $-5.27 * * *$ & $-16.67 * * *$ & $-3.54 * * *$ & $-4.81 * * *$ & -0.17 & $-2.07 * *$ & $-2.17 * *$ & $-5.30^{* * *}$ & $-2.49 * * *$ & $-4.33^{* * *}$ & $-1.58^{*}$ & $-1.91 * *$ \\
\hline $\begin{array}{l}\text { Price of maize (INR base } \\
\text { 2010Q1/quintal) }\end{array}$ & $-4.97 * * *$ & $-11.92^{* * *}$ & $-2.49^{* * *}$ & $-10.61 * * *$ & $-3.11 * * *$ & $-5.05 * * *$ & $-1.78 * *$ & $-4.94 * * *$ & $-2.20 * *$ & $-4.58^{* * *}$ & -1.28 & $-2.81^{* * *}$ \\
\hline $\begin{array}{l}\text { Price of soybean (INR base } \\
\text { 2010Q1/quintal) }\end{array}$ & $-3.82 * * *$ & $-12.62 * * *$ & -1.17 & $-7.76^{* * *}$ & $-3.03^{* * *}$ & $-8.28^{* * *}$ & -0.70 & $-5.00^{* * *}$ & $-1.56^{*}$ & $-2.25 * *$ & 0.18 & $-1.70 * *$ \\
\hline $\begin{array}{l}\text { Price deviation of paddy rice } \\
\text { (INR base 2010Q1/quintal) }\end{array}$ & $-5.27 * * *$ & $-16.67 * * *$ & $-4.05^{* * *}$ & $-5.11 * * *$ & -0.17 & $-2.07 * *$ & $-2.71^{* * *}$ & $-6.55^{* * *}$ & $-2.49 * * *$ & $-4.33^{* * *}$ & $-1.78 * *$ & $-2.05^{* *}$ \\
\hline $\begin{array}{l}\text { Price deviation of maize } \\
\text { (INR base 2010Q1/quintal) }\end{array}$ & $-4.97 * * *$ & $-11.87^{* * *}$ & $-3.00^{* * *}$ & $-9.93 * * *$ & $-3.09 * * *$ & $-5.05 * * *$ & $-2.41^{* * *}$ & $-5.11 * * *$ & $-2.20^{* *}$ & $-4.58^{* * *}$ & $-2.02 * *$ & $-2.85^{* * *}$ \\
\hline $\begin{array}{l}\text { Price deviation of soybean } \\
\text { (INRs base 2010Q1/quintal) }\end{array}$ & $-2.47^{* * *}$ & $-10.12^{* * *}$ & $-1.35^{*}$ & $-7.68 * * *$ & $-4.07^{* * *}$ & $7.79^{* * *}$ & -0.95 & $-5.63^{* * *}$ & $-2.26^{* *}$ & $-2.29 * *$ & 0.14 & $-2.19 * *$ \\
\hline $\begin{array}{l}\text { Oil price (INR base 2010Q1/ } \\
\text { barrel) }\end{array}$ & $-3.10^{* * *}$ & $-15.58^{* * *}$ & 0.08 & $-6.04 * * *$ & $-1.79 * *$ & $-6.82^{* * *}$ & -0.08 & $-5.96^{* * *}$ & -0.39 & $-3.09^{* * *}$ & 0.16 & $-2.38^{* * *}$ \\
\hline Economic growth (rate) & $-7.85^{* * *}$ & - & $-7.29 * * *$ & - & $-6.72 * * *$ & - & $-4.46^{* * *}$ & - & $-7.83^{* * *}$ & - & $-3.37 * * *$ & - \\
\hline $\begin{array}{l}\text { MSP of paddy rice (INR base } \\
\text { 2010Q1/quintal) }\end{array}$ & $-1.51^{*}$ & $-16.84^{* * *}$ & $-2.35^{* * *}$ & $-8.05^{* * *}$ & 1.19 & 0.98 & $-2.27^{* *}$ & $-7.82 * * *$ & $-4.53^{* * *}$ & $-5.25^{* * *}$ & $-1.31^{*}$ & $-2.38^{* * *}$ \\
\hline $\begin{array}{l}\text { MSP of maize (INR base } \\
\text { 2010Q1/quintal) }\end{array}$ & $3.48^{* * *}$ & $-13.99 * * *$ & $-2.25^{* *}$ & $-7.45 * * *$ & $-1.47^{*}$ & $-2.71 * * *$ & $-2.26^{*}$ & $-6.14^{* * *}$ & $-5.91 * * *$ & $-7.00 * * *$ & $-1.94 * *$ & $3.20^{* * *}$ \\
\hline $\begin{array}{l}\text { MSP of soybean (INR base } \\
\text { 2010Q1/quintal) }\end{array}$ & $-3.70^{* * * *}$ & $-12.82 * * *$ & $-1.81 * *$ & $-7.28^{* * *}$ & $-1.73 * *$ & $-3.16 * * *$ & $-1.65 * *$ & $-6.05 * * *$ & $-4.06 * * *$ & $-6.70^{* * *}$ & -1.20 & $-3.46^{* * *}$ \\
\hline
\end{tabular}


The overall coefficient of determination test is used to determine the optimal lag order structure (Abrigo and Love, 2016; Love and Zicchino, 2006), which indicated one lag to be the best PVAR structure for the models of prices and price deviations in the three alternative time frequencies used in this study. In addition, the eigenvalue stability condition test was applied to the three frequency models. This test indicates that all eigenvalues lie inside the unit circle; therefore, all PVAR models satisfy the stability condition (Abrigo and Love, 2016).

The coefficients and their significance for the PVAR(1) models of the first differences when applied to the three commodity prices are tabulated (Table 4), as are the results of the models of the first differences of price deviations between prices paid by wholesalers and the MSP (Table 5). The effects of the first differences of the MSP are significant on the first differences of commodity prices and price deviations with respect to MSP. The results (in both tables) demonstrate the increasing effects of the MSP on prices and price deviations of other commodities, as it reduces most of the remaining cross-commodity price linkages with varying magnitudes, depending on the level of support given by the MSP to each commodity.

Table 4. Main results of the 3 -variable PVAR(1) models of first differences of prices at different frequencies. ${ }^{1,2}$

\begin{tabular}{|c|c|c|c|c|c|c|c|c|c|}
\hline & \multicolumn{3}{|l|}{ Quarterly } & \multicolumn{3}{|l|}{ Semi-annual } & \multicolumn{3}{|l|}{ Annual } \\
\hline & $\begin{array}{l}\text { First diff. } \\
\text { price of } \\
\text { paddy rice }\end{array}$ & $\begin{array}{l}\text { First diff. } \\
\text { price of } \\
\text { maize }\end{array}$ & $\begin{array}{l}\text { First diff. } \\
\text { price of } \\
\text { soybean }\end{array}$ & $\begin{array}{l}\text { First diff. } \\
\text { price of } \\
\text { paddy rice }\end{array}$ & $\begin{array}{l}\text { First diff. } \\
\text { price of } \\
\text { maize }\end{array}$ & $\begin{array}{l}\text { First diff. } \\
\text { price of } \\
\text { soybean }\end{array}$ & $\begin{array}{l}\text { First diff. } \\
\text { price of } \\
\text { paddy rice }\end{array}$ & $\begin{array}{l}\text { First diff. } \\
\text { price of } \\
\text { maize }\end{array}$ & $\begin{array}{l}\text { First diff. } \\
\text { price of } \\
\text { soybean }\end{array}$ \\
\hline $\begin{array}{l}\text { First diff. price of paddy rice (INR } \\
\text { base } 2010 \mathrm{Q} 1 / \text { quintal) (t-1) }\end{array}$ & -0.119 & 0.004 & $0.190 * *$ & $-0.280^{* *}$ & -0.018 & 0.091 & 0.013 & $-0.129 * *$ & $-1.256^{* * *}$ \\
\hline $\begin{array}{l}\text { First diff. price of maize (INR base } \\
\text { 2010Q1/quintal) (t-1) }\end{array}$ & 0.086 & $-0.096^{*}$ & $-0.594 * * *$ & 0.068 & $-0.215^{* * *}$ & $-0.794 * * *$ & 0.056 & $-0.362 * * *$ & $2.032 * * *$ \\
\hline $\begin{array}{l}\text { First diff. price of soybean (INR base } \\
\text { 2010Q1/quintal) (t-1) }\end{array}$ & -0.033 & $0.041^{* * *}$ & $0.134 *$ & 0.032 & $0.063^{* *}$ & 0.148 & -0.020 & $-0.152 * * *$ & -0.161 \\
\hline $\begin{array}{l}\text { First diff. oil price (INR base } \\
\text { 2010Q1/barrel) }\end{array}$ & -0.005 & -0.010 & 0.004 & 0.026 & -0.007 & $0.065 * *$ & $0.058 * *$ & -0.020 & $-0.117^{*}$ \\
\hline Economic growth (rate) & 1.632 & 6.415 & $-36.142 *$ & -10.994 & $12.279 *$ & 27.362 & -9.045 & $39.665^{* * *}$ & $201.494 * * *$ \\
\hline $\begin{array}{l}\text { First diff. MSP of paddy rice (INR } \\
\text { base } 2010 \mathrm{Q} 1 \text { /quintal) }\end{array}$ & 0.199 & 0.025 & -0.456 & 0.271 & -0.013 & $-1.428^{* *}$ & $0.797 * * *$ & $0.434 * * *$ & 1.016 \\
\hline $\begin{array}{l}\text { First diff. MSP of maize (INR base } \\
\text { 2010Q1/quintal) }\end{array}$ & 1.003 & $-0.860^{* *}$ & 0.627 & $1.381 * *$ & $-1.061 * * *$ & $5.453 * * *$ & 0.153 & 0.275 & $6.482 * * *$ \\
\hline $\begin{array}{l}\text { First diff. MSP of soybean (INR base } \\
\text { 2010Q1/quintal) }\end{array}$ & -0.263 & $0.250^{*}$ & $-2.099 * * *$ & -0.269 & $0.442 * * *$ & $-2.753 * * *$ & 0.384 & $0.776^{* * *}$ & 1.124 \\
\hline Dummy quarter 1 & $98.468^{*}$ & $56.265^{* * *}$ & $410.466^{* * *}$ & - & - & - & - & - & - \\
\hline Dummy quarter 2 & $66.427^{* *}$ & 9.729 & $367.683^{* * *}$ & - & - & - & - & - & - \\
\hline Dummy quarter 4 & 1.850 & $-42.740^{*}$ & $295.949 * * *$ & - & - & - & - & - & - \\
\hline Dummy semester 1 & - & - & - & $-82.634 * * *$ & $-56.893 * * *$ & $-158.464 * * *$ & - & - & - \\
\hline Number of states & 6 & & & 6 & & & 6 & & \\
\hline Number of observations & 366 & & & 174 & & & 78 & & \\
\hline
\end{tabular}


Table 5. Main results of the 3-variable PVAR(1) models of first differences of price deviations respect to MSP at different frequencies. ${ }^{1,2}$

\begin{tabular}{|c|c|c|c|c|c|c|c|c|c|}
\hline & \multicolumn{3}{|l|}{ Quarterly } & \multicolumn{3}{|c|}{ Semi-Annual } & \multicolumn{3}{|l|}{ Annual } \\
\hline & $\begin{array}{l}\text { First diff. } \\
\text { price dev. } \\
\text { of paddy } \\
\text { rice }\end{array}$ & $\begin{array}{l}\text { First diff. } \\
\text { price dev. } \\
\text { of maize }\end{array}$ & $\begin{array}{l}\text { First diff. } \\
\text { price dev. } \\
\text { of soybean }\end{array}$ & $\begin{array}{l}\text { First diff. } \\
\text { price dev. } \\
\text { of paddy } \\
\text { rice }\end{array}$ & $\begin{array}{l}\text { First diff. } \\
\text { price dev. } \\
\text { of maize }\end{array}$ & $\begin{array}{l}\text { First diff. } \\
\text { price dev. } \\
\text { of soybean }\end{array}$ & $\begin{array}{l}\text { First diff. } \\
\text { price dev. } \\
\text { of paddy } \\
\text { rice }\end{array}$ & $\begin{array}{l}\text { First diff. } \\
\text { price dev. } \\
\text { of maize }\end{array}$ & $\begin{array}{l}\text { First diff. } \\
\text { price dev. } \\
\text { of soybean }\end{array}$ \\
\hline $\begin{array}{l}\text { First diff. price dev. of paddy rice } \\
\text { (INR base } 2010 \text { Q1/quintal) (t-1) }\end{array}$ & 0.112 & 0.001 & $0.176^{* *}$ & $-0.324 * *$ & -0.024 & -0.037 & -0.035 & $-0.133 * * *$ & -0.206 \\
\hline $\begin{array}{l}\text { First diff. price dev. of maize } \\
\text { (INR base 2010Q1/quintal) (t-1) }\end{array}$ & 0.041 & -0.077 & $-0.900 * * *$ & -0.072 & $-0.206 * * *$ & $-1.032 * * *$ & -0.004 & 0.153 & $3.665^{* * *}$ \\
\hline $\begin{array}{l}\text { First diff. price dev. of soybean } \\
\text { (INR base 2010Q1/quintal) (t-1) }\end{array}$ & -0.031 & $0.033^{* *}$ & $0.148^{* *}$ & 0.001 & $0.058 * * *$ & 0.098 & -0.018 & -0.035 & -0.109 \\
\hline $\begin{array}{l}\text { First diff. oil price (INR base } \\
\text { 2010Q1/barrel) }\end{array}$ & -0.006 & -0.009 & -0.008 & $0.028^{*}$ & -0.007 & $0.069^{* *}$ & $0.060^{*}$ & $-0.040^{* *}$ & $-0.264 * * *$ \\
\hline Economic growth (rate) & 3.205 & 7.764 & -28.587 & -10.456 & 10.945 & 24.077 & -9.904 & $49.000^{* * *}$ & $307.193 * * *$ \\
\hline $\begin{array}{l}\text { First diff. MSP of paddy rice } \\
\text { (INR base 2010Q1/quintal) }\end{array}$ & $-0.797 * * *$ & 0.068 & -0.561 & $-0.583^{* *}$ & 0.038 & $-1.301^{* *}$ & -0.193 & 0.206 & $2.264 * * *$ \\
\hline $\begin{array}{l}\text { First diff. MSP of maize } \\
\text { (INR base 2010Q1/quintal) }\end{array}$ & 0.871 & $-1.869 * * *$ & 0.383 & $1.258^{* *}$ & $-2.064 * * *$ & $5.246 * * *$ & 0.229 & $-1.078^{* * *}$ & 2.726 \\
\hline $\begin{array}{l}\text { First diff. MSP of soybean } \\
\text { (INR base 2010Q1/quintal) }\end{array}$ & -0.207 & $0.258^{* *}$ & $-2.943 * * *$ & -0.166 & $0.430 * * *$ & $-3.572^{* * *}$ & 0.337 & $0.901 * * *$ & 2.895 \\
\hline Dummy quarter 1 & 89.962 & $52.223 * *$ & $386.182 * * *$ & - & - & - & - & - & - \\
\hline Dummy quarter 2 & $67.493^{*}$ & 7.388 & $373.868 * * *$ & - & - & - & - & - & - \\
\hline Dummy quarter 4 & 6.245 & $-48.110 * *$ & $311.733^{* * *}$ & - & - & - & - & - & - \\
\hline Dummy semester 1 & - & - & - & -43.649 & $-52.516^{* * *}$ & $-87.535^{*}$ & - & - & - \\
\hline Number of states & 6 & & & 6 & & & 6 & & \\
\hline Number of observations & 366 & & & 174 & & & 78 & & \\
\hline
\end{tabular}

In cases like the MSP for paddy rice, the effect of the policy on soybean prices and price deviations completely offsets the magnitude of the price linkages, given the not significant effect of the price linkages. These effects of the MSP on commodity prices could introduce distortions that affect the price incentives that guide land allocation and production, which would then negatively affect the performance of these agro-food chains (Norwood and Lusk, 2008; Tomek and Kaiser, 2014). These results corroborate the findings of Aditya et al. (2017), Chand (2003) and Singh et al. (2002), who reported reallocations of land from oilseeds to paddy and wheat as a response to the MSP favouring food crops over other crops. As expected, given the construction of the price deviation with respect to MSP, for the same commodity the MSP has a negative effect on the first differences of the price deviations between prices paid by wholesalers and the MSP (see estimations presented in Table 5).

The most relevant remaining price linkages between commodities after removing the effects of MSP are the impacts of the variations in maize prices and price deviations in soybean prices. Such a strong price linkage could be related to the alternative use of these two commodities to produce biofuels, as discussed by De Gorter et al. $(2013,2015)$. The sign of the impacts varies between the semi-annual and annual results, possibly resulting from the semi-annual frequency reflecting the price variations observed between seasons, while the annual frequency results capture variations of the MSP over years. In addition, the macroeconomic variables and the seasonal and quarter dummies show different levels of significance, depending on the frequencies 
used. Both estimations show significant effects of the first differences of the MSP across commodities, which demonstrates the offsetting effect of variations of the MSP on price linkages between commodities.

The IRF of the three-variable PVAR(1) models after removing the effects of the MSP on commodity prices for quarterly and semi-annual frequencies is presented graphically (Figures 2 and 3). These figures present the first differences for the three commodity prices and price deviations with respect to the MSP with one lag, with a $95 \%$ confidence interval that was estimated by 1000 Monte Carlo simulations of the fitted reduced-form distribution of each PVAR model. The IRF for the quarterly PVAR(1) models of first differences of prices and price deviations (Figure 2) shows a negative impact of a one INR shock on price and price deviations with respect to the MSP of maize in soybean. The semi-annual PVAR(1) (Figure 3) shows a negative effect of a one INR shock of maize on the first differences of soybean prices and price deviations with respect to the MSP during the next season (half year), which becomes positive after another half year. This result can be explained by the cyclical variation in prices through the MSP year, which generally starts with low prices and gradually increases until the beginning of the following year.

A
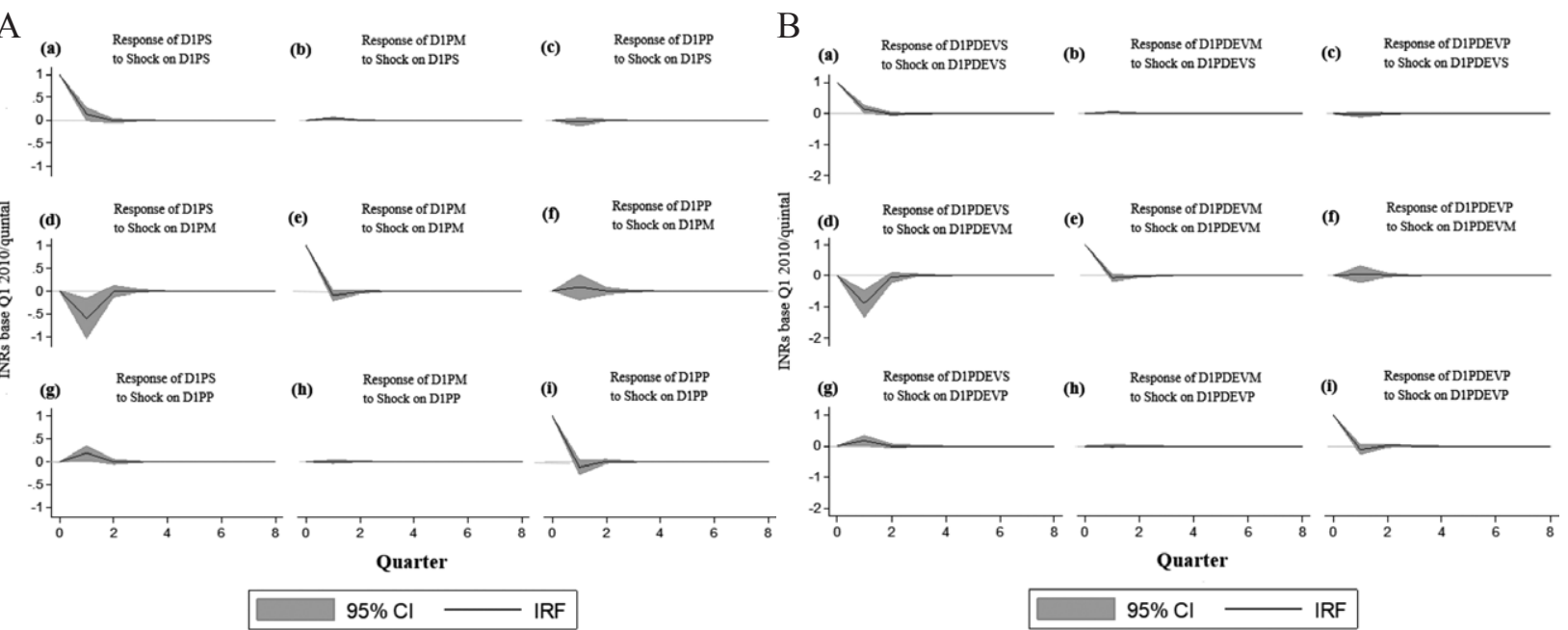

Figure 2. Quarterly impulse response functions of PVAR(1) to one INR shock on first differences of (A) prices and (B) price deviations with respect to MSP of each commodity.
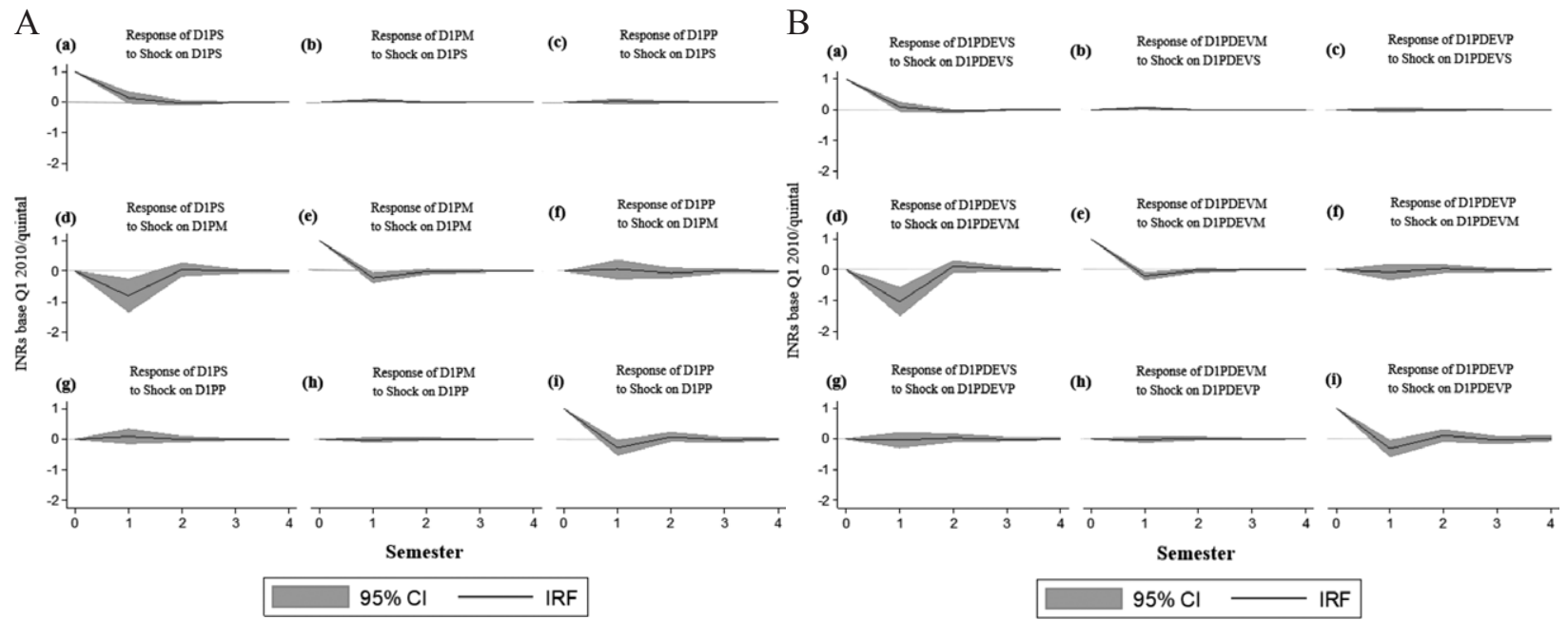

Figure 3. Semi-annual impulse response functions of PVAR(1) to one INR shock on first differences of (A) prices and (B) price deviations with respect to MSP of each commodity. 
Annual PVAR(1) models are used to provide evidence of a positive impact of a one INR shock on maize in soybean first differences of prices as well as price deviations with respect to the MSP during the next year period (Figure 4). Again, this price linkage can be explained by variations in demand due to the alternative use of maize and soybean to produce biofuels. Moreover, no impact is observed on the soybean price of shocks on paddy rice prices when analysing price deviations with respect to the MSP. The absence of transmission in this case could be related to the dampening effects of the MSP policy. These results demonstrate the existence of cross-commodity price linkages between cereals and oilseeds that remain in Indian agricultural markets even once the effects of the MSP policy are taken into consideration. Therefore, it is demonstrated that price shocks on maize are transmitted to soybean prices, regardless of the fact that the MSP protection for soybean is lower than that for cereals.

Considering the differences in the lagged period included in the models for the different frequencies, two models for quarterly PVAR(4) and semi-annual PVAR(2) were estimated as robustness tests to make the period covered in the models comparable to an annual PVAR(1). Some minor differences between the first differences of price and price deviation quarterly models are observed (Figure 5). The latter display a similar pattern to that exhibited in the quarter PVAR(1) for price deviations (Figure 2). Additionally, a negative effect is observed on soybean price of a shock on the first difference of maize price deviations, which decreases to zero during the next quarter. The IRF (Figure 6) shows a pattern similar to that observed in the case of the semi-annual PVAR(1) (Figure 3), with a negative effect of a one INR shock on maize on soybean first differences of prices and price deviations during the next season. However, this effect becomes positive when a full year is completed.

The IRFs obtained in each case are very similar for the PVAR of prices and price deviations. This could be explained by the average modal prices paid by wholesalers during the period under analysis being above the MSP for the commodities studied. The differences in the results obtained for the three alternative frequencies demonstrate that comparing high-frequency and low-frequency data (semi-annual and annual) allows for a better modelling of Indian agricultural markets at farmer-wholesaler level within and between production cycles. The variations in the results can be attributed to the characteristics of these commodity markets, which are influenced by production cycles, previously agreed contracts, limited infrastructure, which includes farmers' storage capacity, and lags on price transmission, as indicated by Conforti (2004), Fackler and Goodwin (2001) and Meyer and Von Cramon-Taubadel (2004).
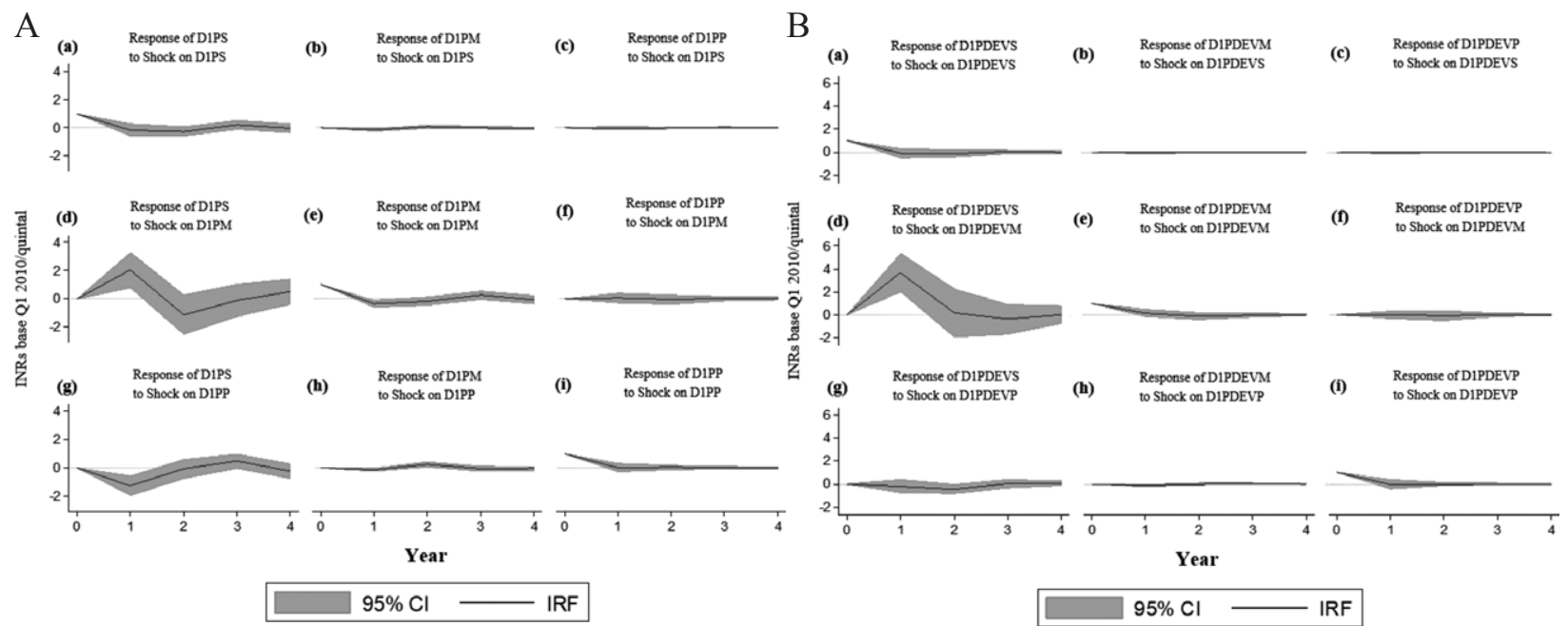

Figure 4. Annual impulse response functions of PVAR(1) to one INR shock on first differences of (A) prices and (B) price deviations with respect to MSP of each commodity. 
A

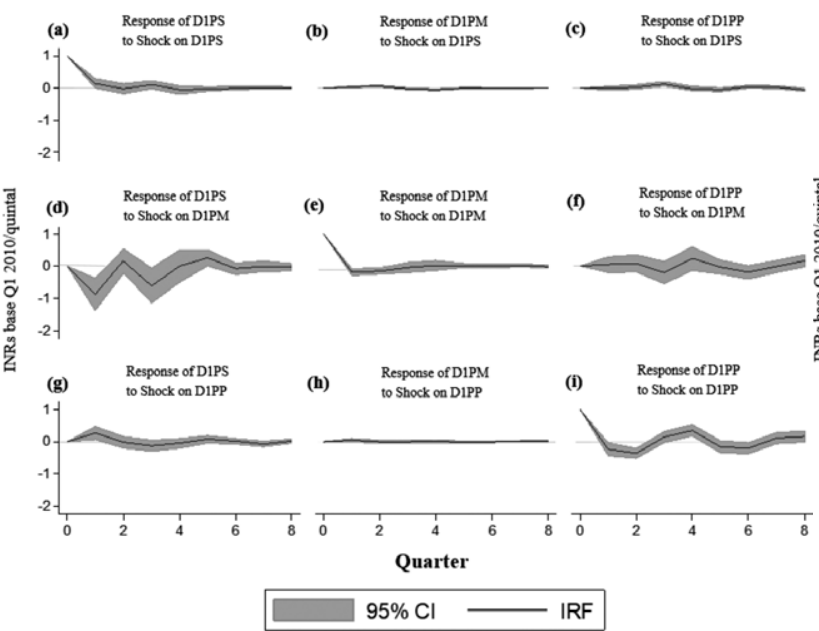

B

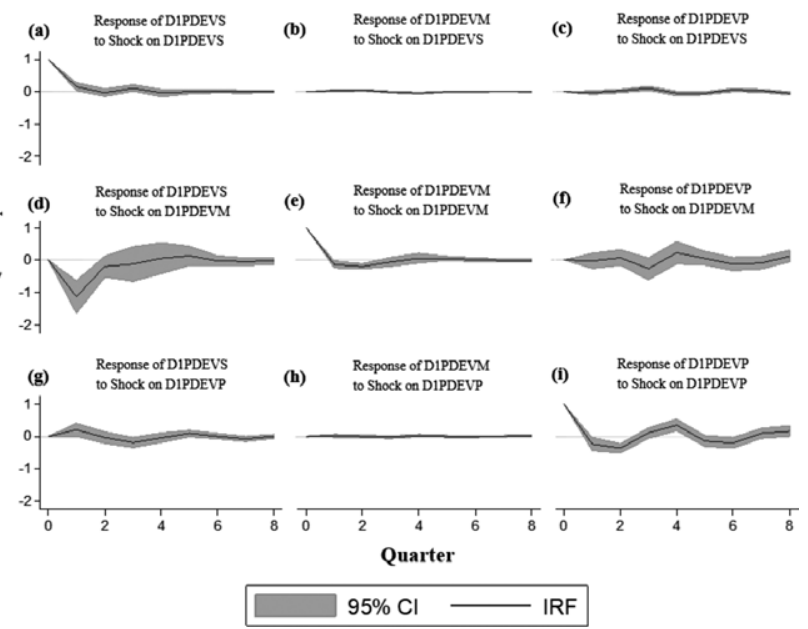

Figure 5. Quarterly impulse response functions of PVAR(4) to one INR shock on first differences of (A) prices and (B) price deviations with respect to MSP of each commodity.
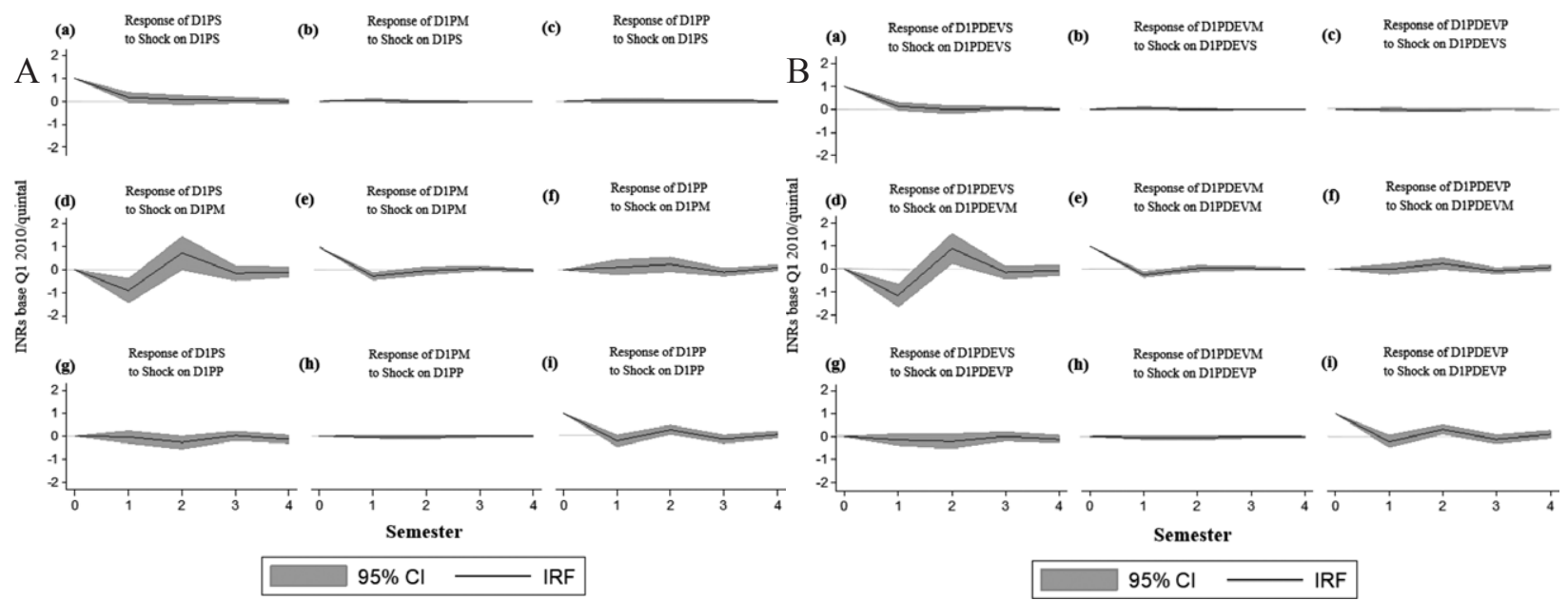

Figure 6. Semi-annual impulse response functions of PVAR(2) to one INR shock on first differences of (A) prices and (B) price deviations with respect to MSP of each commodity.

\section{Conclusions}

Several developed and developing countries, including India, have implemented price interventions as a way of guaranteeing food security and supporting small farmers' welfare, reducing price risk at production level and ultimately encouraging farmers' own investment on specific agricultural products, even though it is widely recognized that price support policies are inefficient. However, what are the impacts of these price support policies in terms of cross-commodity price linkages? What are the expected effects of the MSP policy on production, resource allocation and ultimately competitiveness of agro-food industries? Are changes in the MSP offsetting price linkages between agricultural commodities? This research addresses these questions in the case of India, which is a large country in terms of production and consumption of rice, maize and soybeans. The extent of market integration of these three commodities were examined in the context of the MSP policy that has been implemented for several decades by the government of India. To the best of our knowledge, this is the first study that has analysed the dynamic linkages between commodity prices under intervention in India or any other country. This research contributes to the literature by testing whether price relationships remain between cereals and oilseeds once the price distortions introduced by the MSP policy are taken into account. 
This research used panel data from six states of India and applied a PVAR model to analyse the relationships between the prices of paddy rice, maize and soybean. The empirical results demonstrate the offsetting effects of the MSP on price linkages between the three commodities; these effects are captured in the first differences of prices and price deviations from the MSP for the three commodities. These results demonstrate the negative effects of MSP on cross-commodity price linkages, which can introduce price distortions that might potentially affect resource allocation, production and the overall performance of these agro-food chains, in line with the outcomes reported by Aditya et al. (2017), Chand (2003) and Singh et al. (2002).

The most relevant remaining price linkages after removing the effect of the MSP are those between maize and soybean, whereby a price increase in maize results in a price increase in soybean during the next MSP year. This finding adds to the outcomes reported by Kumar (2006) within commodity complexes and corroborates the results of Ai et al. (2006), Pindyck and Rotemberg (1990) and Saadi (2011), who reported linkages between agricultural commodity price series based on their co-movements. In addition, the comparison of results with different frequencies demonstrates that models using low-frequency data can capture relationships between production periods of Indian agricultural markets between farmers and wholesalers, as it is a level that is known to be affected by lags in price transmission, production cycles and previously agreed contracts.

There are several implications of these findings. First, there is evidence that the MSP policy partially and completely offsets price linkages between agricultural commodities. It was found that for the effect of paddy rice price on soybean price, the cross-commodity price linkages are either not significant or negative, and that the magnitude of the MSP on paddy rice completely offsets the price linkages between the two commodities, with the possibility that the offset could be even bigger than the price linkages. In this scenario, the MSP can introduce price distortions that can modify incentives for resource allocation and production between commodities. Second, the Indian authority can expect some remaining transmission of price shocks from maize to soybean over the next period and production year, even though the level of intervention on soybean is lower than that provided for cereals.

Indian policy makers could find these results useful for exploiting the full potential of market forces and price linkages to ensure an optimal allocation of resources across agricultural commodities. Finally, the analysis of high-frequency and low-frequency data allows to better capture the characteristics of agricultural markets at farmer-wholesaler level in the context of India, where price transmission and linkages are affected by several factors. Consequently, researchers might consider comparing the results obtained using different frequencies to determine the alternative that better fits the characteristics of the market under analysis.

Future research could investigate linkages between commodity prices at district level, as their relationships could vary within each state, given the large size of India and the varied marketing and climate conditions across states. Future studies could also analyse and contrast cross-commodity price linkages between countries that produce similar products, as the results obtained in this research might not represent the dynamics of commodity markets in other countries.

\section{Acknowledgements}

The authors are grateful to Guillaume Pierre, Susan Jessop and Melissa Mitchell for providing valuable support. The authors also wish to thank all staff of the Agricultural Development Economics Division (ESA) who participated in a FAO seminar and provided several helpful comments and suggestions. Special thanks to the professionals of the teams Monitoring and Analysing Food and Agricultural Policies (MAFAP), Economics and Policy Innovations for Climate-Smart Agriculture (EPIC), Small Family Farms and Global Perspectives Studies for their constant support. Finally, the authors are also grateful to the Editor and Reviewers of this journal for their valuable time devoted to review this manuscript and for providing very helpful comments and suggestions. This research did not receive any specific grant from funding agencies in the public, commercial, or not-for-profit sectors. 
The data used in this research is from public sources. The data has been submitted and it will be made available upon request.

\section{References}

Abrigo, M.R.M. and I. Love. 2016. Estimation of panel vector autoregression in Stata. Stata Journal 16(3): 778-804.

Acharya, S.S. 1997. Agricultural price policy and development: some facts and emerging issues. Indian Journal of Agricultural Economics 52(1): 1-47.

Acharya, S.S., R. Chand, P.S. Birthal, S. Kumar and D.S. Negi. 2012. Market integration and price transmission in India: a case of rice and wheat with special reference to the world food crisis of 2078/08. Food and Agriculture Organization of the United Nations, Office of Knowledge Exchange, Research and Extension, Rome, Italy. Available at: http://www.fao.org/3/a-an034e.pdf

Aditya, K.S., S.P. Subash, K.V. Praveen, M.L. Nithyashree, N. Bhuvana and A. Sharma. 2017. Awareness about minimum support price and its impact on diversification decision of farmers in India. Asia and The Pacific Political Studies 4(3): 514-526.

Ahn, B. and H. Lee. 2015. Vertical price transmission of perishable products: the case of fresh fruits in the Western United States. Journal of Agricultural and Resource Economics 40: 405-424.

Ai, C., Chatrath, A. and Song, F. 2006. On the co-movement of commodity prices. American Journal of Agricultural Economics 88(3): 574-588.

Ali, S.Z., R.S. Sidhu and K. Vatta. 2012. Effectiveness of minimum support price policy for paddy in India with a case study of Punjab. Agricultural Economics Research Review 25(2): 231-242.

Arellano, M. and O. Bover. 1995. Another look at the instrumental variable estimation of error-components models. Journal of Econometrics 68: 29-51.

Baltagi, B.H. 2013. Econometric analysis of panel data, $5^{\text {th }}$ edition. John Wiley and Sons, West Sussex, UK.

Baquedano, F.G. and W.M. Liefert. 2014. Market integration and price transmission in consumer markets of developing countries. Food Policy 44: 103-114.

Breitung, J. and S. Das. 2005. Panel unit root tests under cross-sectional dependence. Statistica Neerlandica 59: 414-433.

Byrne, J.P., G. Fazio and N. Fiess. 2013. Primary commodity price: co-movements, common factors and fundamentals. Journal of Development Economics 101: 16-26.

Chand, R. 2003. Minimum support price in agriculture: changing requirements. Economic and Political Weekly 38(29): 3027-3028.

Chand, R. 2008. MSP and other interventions in wheat market: are they contributing to the buffer stock cycles and market destabilization? Available at: https://citeseerx.ist.psu.edu/viewdoc/ download?doi=10.1.1.620.3112\&rep=rep1\&type $=$ pdf

Conforti, P. 2004. Price transmission in selected agricultural markets. FAO Commodity and Trade Policy Research Working Paper No. 7. Food and Agriculture Organization of the United Nations, Rome, Italy. Available at: http://www.fao.org/tempref/docrep/fao/006/ad766e/ad766e00.pdf.

Dawe, D. and C.P. Timmer. 2012. Why stable food prices are a good thing: lessons from stabilizing rice prices in Asia. Global Food Security 1: 127-133.

Dawe, D., C. Morales-Opazo, J. Balie and G. Pierre. 2015. How much have domestic food prices increased in the new era of higher food prices? Global Food Security 5: 1-10.

De Gorter, H., D. Drabik and D.R. Just. 2013. How biofuels policies affect the level of grains and oilseed prices: theory, models and evidence. Global Food Security 2: 82-88.

De Gorter, H., D. Drabik and D.R. Just. 2015. The economics of biofuel policies: impacts on price volatility in grain and oilseed markets. Palgrave Macmillan, New York, NY, USA.

Deaton, A. 1999. Commodity prices and growth in Africa. Journal of Economic Perspectives 13(3): 23-40.

Dethier, J.J. and A. Effenberg. 2012. Agriculture and development: a brief review of the literature. Economic Systems 36(2): 175-205.

Ellis, F. 1992. Agricultural policies in developing countries. Cambridge University Press, Cambridge, UK. Enders, W. 2014. Applied econometric time series, $4^{\text {th }}$ edition. John Wiley and Sons, Hoboken, NJ, USA. 
Esposti, R. and G. Listorti. 2013. Agricultural price transmission across space and commodities during price bubbles. Agricultural Economics 44: 125-139.

Fackler, P.L. and B.K. Goodwin. 2001. Spatial price analysis. In: B.L. Gardner and G.C. Rausser (eds.) Handbook of agricultural economics. Vol. 1B. Elsevier Science, Amsterdam, the Netherlands, pp. 971-1024.

Food and Agriculture Organization of the United Nations (FAO), International Fund for International Development (IFAD) and World Food Programme (WFP). 2011. The state of food insecurity. FAO Publishing Policy and Support Branch, Rome, Italy.

Government of India, Ministry of Agricultural Costs and Prices (MACP). 2018. Minimum support prices. Available at: https://cacp.dacnet.nic.in

Government of India, Ministry of Statistics and Programme Implementation (MSPI). 2018. Statistical year book India 2017. Available at: http://mospi.nic.in/statistical-year-book-india/2017/177

Government of India, Open Government Data Platform India (OGDP). 2018. Variety-wise daily market prices. Available at: https://data.gov.in

Greene, W.H. 2018. Econometric analysis, $8^{\text {th }}$ edition. Pearson Prentice Hall, Upper Saddle River, NJ, USA.

International Monetary Fund (IMF). 2018. IMF data. IMF, Washington, DC, USA. Available at: http://www. imf.org/en/Data

Jayne, T.S., R.J. Myers and J. Nyoro. 2008. The effects of NCPB marketing policies on maize market prices in Kenya. Agricultural Economics 38: 131-325.

Kao, C. 1999. Spurious regression and residual-based tests for cointegration in panel data. Journal of Econometrics 90: 1-44.

Klein, N. 2009. The linkage between the oil and nonoil sectors - a panel VAR approach. IMF Working Paper, WP/10/118. IMF, Washington, DC, USA. Available at: https://www.imf.org/external/pubs/ $\mathrm{ft} / \mathrm{wp} / 2010 / \mathrm{wp} 10118 . \mathrm{pdf}$

Kumar, P. 2006. Inter commodity price linkages in India: a case of foodgrains, oilseeds and edible oils. Journal of International and Area Studies 13(1): 103-126.

Levin, A., C.F. Lin and C. Chu. 2002. Unit root test in panel data: asymptotic and finite sample properties. Journal of Econometrics 108: 1-24.

Love, I. and L. Zicchino. 2006. Financial development and dynamic investment behavior: evidence from panel VAR. The Quarterly Review of Economics and Finance 46: 190-210.

Magrini, E., J. Balié and C. Morales-Opazo. 2017a. Price signals and supply responses for staple food crops in sub-Saharan Africa. Applied Economic Perspectives and Policy 40(2): 276-296.

Magrini, E., J. Balié and C. Morales-Opazo. 2017b. Cereal price shocks and volatility in sub-Saharan Africa: what really matters for farmers' welfare? Agricultural Economics 48(6): 719-729.

McCorriston, S. and D. MacLaren. 2016. Parastatals as instruments of government policy: the Food Corporation of India. Food Policy 65: 53-62.

Meyer, J. and S. Von Cramon-Taubadel. 2004. Asymmetric price transmission: a survey. Journal of Agricultural Economics 55(3): 581-611.

Myers, R.J., R.R. Piggott and W.G. Tomek. 1990. Estimating sources of fluctuations in the Australian wool market: an application of VAR methods. Australian Journal of Agricultural Economics 34(3): 242-262.

Minot, N. 2014. Food price volatility in sub-Saharan Africa: has it really increased? Food Policy 45: 45-56.

Mittal, S., V.K. Hariharan and S.P. Subash. 2018. Price volatility trends and price transmission for major staples in India. Agricultural Economics Research Review 31(1): 65-74.

Morales, L.E. 2018. The effects of international price volatility on farmer prices and marketing margins in cattle markets. International Food and Agribusiness Management Review 21(3): 335-349.

Morales, L.E., N. Hoang and E. Stuen. 2017. Spatial price premium transmission for Meat Standards Australia-graded cattle: the vulnerability of price premiums to outside shocks. Australian Journal of Agricultural and Resource Economics 61(4): 590-609.

Newton, J. 2016. Price transmission in global dairy markets. International Food and Agribusiness Management Review 19(B): 57-72.

Norwood, F.B. and Lusk, J.L. 2008. Agricultural marketing and price analysis. Pearson Prentice Hall, Upper Saddle River, NJ, USA. 
Nourou, M. 2015. Can mastitis 'contaminate' poultry? Evidence on the transmission of volatility between poultry and other commodity prices. International Food and Agribusiness Management Review 18: 183-196.

Organisation for Economic Co-operation and Development (OECD). 2018a. Agricultural policy monitoring and evaluation. OECD, Paris, France. Available at: https://www.oecd-ilibrary.org/agriculture-andfood/agricultural-policy-monitoring-and-evaluation-2018_agr_pol-2018-en

Organisation for Economic Co-operation and Development (OECD). 2018b. OECD stat. OECD, Paris, France. Available at: https://stats.oecd.org

Organization of the Petroleum Exporting Countries (OPEC). 2018. OPEC oil basket prices. OPEC, Vienna, Austria.

Palaskas, T.B. and P.N. Varangis. 1991. Is there excess co-movement of primary commodity prices? A cointegration test. Working Paper Series 758. International Economic Department, World Bank, Washington, DC, USA. Available at: http://documents.worldbank.org/curated/en/501741468764366821/ Is-there-excess-co-movement-of-primary-commodity-prices-A-co-integration-test

Pesaran, M.H. 2004. General diagnostic tests for cross-section dependence in panels. CESifo Working Paper Series No. 1229; IZA Discussion Paper No. 1240. Available at: http://ssrn.com/abstract=572504

Pindyck, R.S. and J.J. Rotemberg. 1990. The excess co-movement of commodity prices. The Economic Journal 100: 1173-1189.

Rapsomanikis, G. and H. Mugera. 2011. Price transmission and volatility spillovers in food markets of developing countries. In: I. Piot-Lepetit and R. M'Barek (eds.) Methods to analyse agricultural commodity price volatility. Springer, Dordrecht, the Netherlands, pp. 165-179.

Rezitis, A.N. 2018. Empirical analysis of price relations along the Finnish supply chain of selected meat, dairy and egg products: a dynamic panel data approach. Agribusiness 34: 542-561.

Saadi, H. 2011. Price co-movements in international markets and their impacts on price dynamics. In: I. Piot-Lepetit and R. M'Barek (eds.) Methods to analyse agricultural commodity price volatility. Springer, Dordrecht, the Netherlands, pp. 149-163.

Saini, S. and A. Gulati. 2017. Price distortions in Indian agriculture. Indian Council for Research on International Economic Relations (ICRIER), New Delhi, India. Available at: http://icrier.org/pdf/ Price Distortions in Indian_Agriculture 2017.pdf

Sekhar, C.S.C. 2012. Agricultural market integration in India: an analysis of select commodities. Food Policy 37: 309-322.

Sims, C.A. 1980. Macroeconomics and reality. Econometrica 48: 1-48.

Singh, K., K. Vatta and S. Kumar. 2002. Effectiveness of price policy for cotton in Punjab. Indian Journal of Agricultural Marketing 16(3): 65-72.

Tomek, W.G. and H.M. Kaiser. 2014. Agricultural product prices, $5^{\text {th }}$ edition. Cornell University Press, Ithaca, NY, USA. 